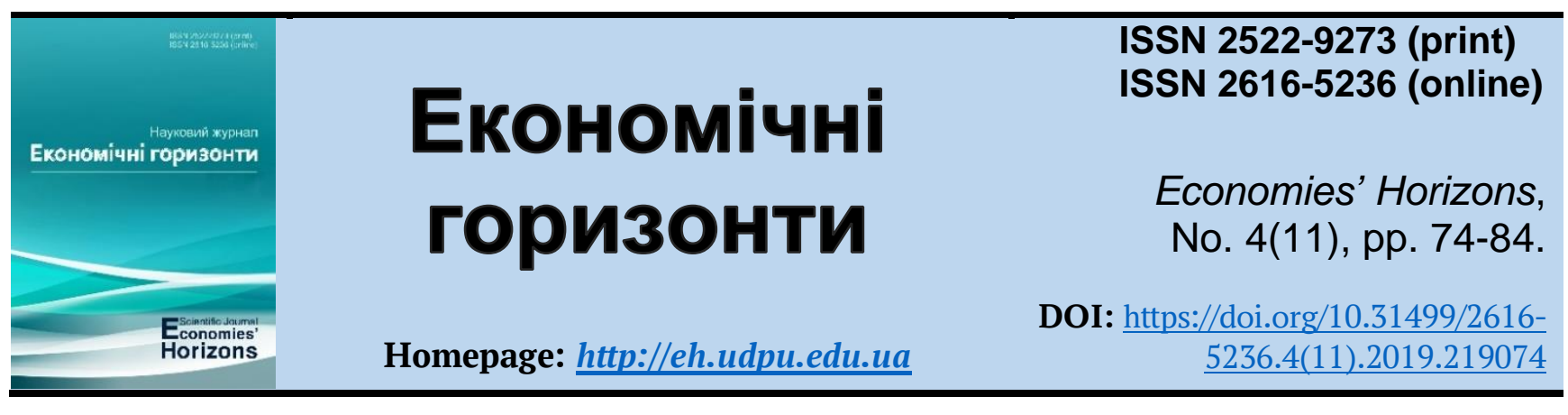

UDC 332.142

\title{
The impact of structural changes in the economy on employment as a basic factor of the region's social development
}

Received: 24 October 2019

Accepted: 29 November 2019

\author{
Dmytro S. Voit ${ }^{1}$, Cand. Ec. Sc.
}

Voit, D. S. (2019), "The impact of structural changes in the economy on employment as a basic factor of the region's social development", Economies' Horizons, no. 4(11), pp. 74-84, doi: https://doi.org/10.31499/2616-5236.4(11).2019.219074

Abstract. The purpose of the article is to study the impact of structural changes in the economy on employment as a basic factor of the region's social development. Methodology. The general scientific methods are used in the research, in particular: theoretical generalization - to study the impact of structural changes in the region's economy; statistical analysis - to analyze the characteristics of the current, employed population and the average monthly salary; methods of positive and normative analysis - to substantiate the impact of structural changes in the economy on employment as a basic factor of the region's social development. Results. It is noted that providing a sufficient employment rate and decent working conditions is one of the important indicators and, at the same time, factors of socio-economic development of the region. In order to determine the dependence of employment in Dnipropetrovsk region on the influence of the structural, regional and national factors, a shift-share analysis was conducted. The results of the analysis showed that the greatest influence on providing the employment rate in the Dnipropetrovsk region is exerted by the factors of the regional economy, namely the competitiveness of the sectors, including primarily industry, wholesale and retail trade, transport. Almost all types of economic activity are internally competitive, which in 2018 provided the current employment rate by $89 \%$, i. e. $1,245.4$ thousand employees. Given the preservation of national dynamics in the region, the number of employees in the region as a whole would be lower by $9 \%$ or 133 thousand people. The largest reductions would be in industry, trade and education. The graphic analysis of employment in terms of economic activities in Dnipropetrovsk region revealed the most promising economy sectors in the region in terms of job creation and providing a sufficient employment rate. Each type of economic activity is represented by a point with corresponding coordinates, which shows the growth of employment in the sector at the national $(X)$ and regional level $(Y)$ and the share of economic activity in the region's economy. Practical meaning. The graphic analysis shows that the most productive sectors of the region's economy in terms of job growth are wholesale and retail trade, agriculture and forestry. Prospects for further research. The research shows that the main problem of managing the region's strategic development at the current stage is primarily the lack of a comprehensive conceptual strategic vision of the region's model, which will provide a balance of interests between government, business, the public, unite the efforts of all actors in the regional system to achieve common and mutually beneficial goals aimed at sustainable economic growth, providing the

\footnotetext{
${ }^{1}$ International University of Business and Law; Doctoral Student; ORCID ID: https://orcid.org/0000-00033406-2237; e-mail: management@nuos.edu.ua.
} 
welfare of citizens and the most optimal use of resources. Such goals, in our opinion, should be the imperatives of strategic development of the region, which will act as a cross-cutting regulator of socioeconomic processes and decision-making at all levels.

Keywords: structural changes, employment, regional development, socialization.

JEL Classification: H00, H11, H19, H55, H77.

Number of references: 15; number of tables: 1; number of figures: $\mathbf{0}$; number of formulas: $\mathbf{0 .}$

\title{
Вплив структурних зрушень в економіці на рівень зайнятості населення як базового чинника соціального розвитку регіону
}

\author{
Дмитро Сергійович Войт ${ }^{1}$, к. е. н.
}

Стаття надійшла: 24.10.2019

Стаття прийнята: 29.11.2019
Voit D. S. The impact of structural changes in the economy on employment as a basic factor of the region's social development. Економічні горизонти. 2019. № 4(11). C. 74-84. DOI: 10.31499/2616-5236.4(11).2019.219074

Анотація. Метою статті є дослідження впливу структурних зрушень в економіці на рівень зайнятості населення як базового чинника соціального розвитку регіону. Методологія. У досліджені застосовані загальнонаукові методи, зокрема: теоретичне узагальнення - для впливу структурних зрушень в економіці регіону; статистичного аналізу - для аналізу характеристики наявного, зайнятого населення та середньомісячної заробітної плати; методи позитивного і нормативного аналізу - для обгрунтування впливу структурних зрушень в економіці на рівень зайнятості населення як базового чинника соціального розвитку регіону. Результати. Зазначено, що одним з важливих показників і, водночас, факторів соціально-економічного розвитку регіону є забезпечення достатнього рівня зайнятості населення та гідних умов праці. 3 метою визначення залежності рівня зайнятості у Дніпропетровській області від впливу структурних, регіональних та національних чинників проведено "Shift-share" аналіз. Результати аналізу показали, що найбільший вплив на забезпечення рівня зайнятості у Дніпропетровській області здійснюються фактори регіональної економіки, а саме конкурентоспроможність більшості секторів, серед яких насамперед промисловість, оптова і роздрібна торгівля, транспорт. Майже всі види економічної діяльності $\epsilon$ внутрішньо конкурентоспроможними, що забезпечило у 2018 році поточний рівень зайнятості на 89\%, тобто 1245,4 тис. працюючих. За умови збереження загальнонаціональної динаміки в області чисельність занятих в цілому по регіону була б нижчою на 9\% або на 133 тис. осіб. Найбільшого скорочення зазнали б сектори: промисловість, торгівля та освіта. Здійснено графічний аналіз зайнятості у розрізі видів економічної діяльності в Дніпропетровській області, що дозволив виявити найбільш перспективні з точки зору створення робочих місць та забезпечення достатнього рівня зайнятості населення в регіоні сектори економіки. Кожний вид економічної діяльності представлений точкою з відповідними координатами, що показує зростання зайнятості населення в цьому секторі на національному $(X)$ та регіональному рівні (Y), а також питому вагу виду економічної діяльності в економіці регіону. Практичне значення. Графічний аналіз показав, що найбільш продуктивними секторами господарства регіону з точки зору забезпечення зростання кількості робочих місць $\epsilon$ оптова та роздрібна торгівля та сільське та лісове господарство. Перспективи подальших досліджень. Проведені дослідження показали, що основною проблемою управління стратегічним розвитком регіону на сучасному етапі $є$ насамперед відсутність комплексного концептуального бачення моделі функціонування регіону у стратегічній перспективі, що забезпечуватиме баланс інтересів між владою, бізнесом, громадськістю, об’єднуватиме зусилля всіх суб’єктів регіональної системи на досягнення спі-

\footnotetext{
${ }^{1}$ Міжнародний університет бізнесу і права; докторант; ідентифікатор ORCID: https://orcid.org/00000003-3406-2237; e-mail:management@nuos.edu.ua.
} 
льних і взаємовигідних цілей орієнтованих на стале економічне зростання, забезпечення добробуту громадян та найбільш оптимальне використання ресурсів.

Ключові слова: структурні зрушення, зайнятість населення, розвиток регіону, соціалізація

Кількість джерел: 15; кількість таблиць: 1; кількість рисунків: 0; кількість формул: 0.

\section{Introduction.}

Providing a sufficient employment rate and decent working conditions is one of the important indicators and, at the same time, factors of socio-economic development of the region. According to U. Sadova and T. Stepura "In Ukraine, the strategic goals of providing decent working conditions are difficult to achieve. Along with globalization, there are factors of military conflict in the east of the country; there are consequences of a prolonged economic crisis. At the same time, new phenomena are being recorded in the labor market. There is a transformation of employment forms, changes in its structure in terms of economic activity; there is also the development of non-standard employment, the emergence of "borrowed" labor, outsourcing, freelancing and other new models and approaches to employment. In the current conditions, there is an issue of effective regulation of the process of maintaining existing jobs and creating new ones" (Sadova and Stepura, 2018).

\section{Literature review.}

Ukrainian and foreign scientists have paid considerable attention to the study of structural changes in the economy on employment as a basic factor of the region's social development. They are U. Sadova and T. Stepura (2018), I. Kramarenko, D. Voit and L. Kravets, (2019), A. Slashchuk and Z. Popyuk (2013), L. Strembitska (2017), L. Fedunchyk (2017), I. Irtyshcheva, D. Voit, H. Pavlenko, and A. Arhangelska, (2019), E. Luboš, L. Lesáková, V. Klementová, and L. Klement (2019), N. Grineva (2010), T. Trubnik and O. Mazurenko (2019), M. Zsarnoczky (2018) and others. However, the constant processes of socialization and its active institutionalization require additional research on the impact of structural changes in the economy on employment as a basic factor of the region's social development.

\section{Methodology.}

The scientific works of scientists in managing the social development of the region are the theoretical and methodological basis of the study. To achieve the purpose of the study, the following research methods were used: theoretical generalization - to study the impact of structural changes in the region's economy; statistical analysis - to analyze the characteristics of the current, employed population and the average monthly salary; methods of positive and normative analysis - to substantiate the impact of structural changes in the economy on employment as a basic factor of the region's social development.

\section{Research objectives.}

The purpose of the article is to study the impact of structural changes in the economy on employment as a basic factor of the region's social development.

\section{Results and discussions.}

Satisfaction of the population's needs is due to their earnings from work, i.e. due to employment. Employment provides an opportunity to provide the livelihood of the community. Moreover, at the expense of employment there is a provision not only for the working population, but also 
for the disabled. Employment encourages the self-development of each individual, and in general - provides the quality of the workforce. Employment is related to the reproduction of the population through the reproduction of the personal factor of production and the satisfaction of personal and social needs. In turn, the use of the labor potential of society is associated with the age and gender structure of the working population.

It should be noted that recently the issue of youth employment has become increasingly important. According to the State target social program "Youth of Ukraine" for 2016-2020 “The participation of young people in the socio-political life of the state and the formation of policies on issues affecting their lives, development and solving urgent problems remains quite low. Only 5 percent of young people participated in the discussion of bills at the state or local level" (Cabinet Ministers of Ukraine, 2016). Activities at the international, national and regional levels on employment and legal education of young people are ongoing: competitions, conferences, round tables, symposia, seminars, trainings, forums, festivals, etc. The Ministry of Social Policy, the authorities, public organizations and regional youth centers are developing information and methodological brochures and making short films of social orientation and social advertising.

According to the State Statistics Service, the highest unemployment rate is among young people aged $15-24$, it is $17.9 \%$. In the second place in terms of unemployment is young people aged 25-29; for this category, the unemployment rate is $9.8 \%$. Next is the age category of 35-39 years with an unemployment rate of $9.5 \%$, and then comes the age category of 30-34 years with an unemployment rate of $8.9 \%$ (State Statistics Service of Ukraine, 2019).

Important aspects of the social policy of youth employment are the support and development of the innovative potential of young people, as well as the promotion of a safe lifestyle, maintaining physical, mental and reproductive health, general safety of life. Non-formal education is being actively implemented in order to improve youth employment. Through non-formal education, young people have the opportunity to learn a new profession, to acquire certain competencies to improve professional knowledge and career opportunities.

Provision of employment, especially among young people, in the region is one of the priorities of regional authorities, as high employment rate (aimed at creating material or spiritual goods and with sufficient salaries to provide a decent standard of living) contribute to the domestic market development, increasing business activity in the region, filling the state and regional budgets and reducing social tensions.

Thus, employment combines economic and social aspects. The economic aspects are that employment is an important factor in the production sector and services, and also forms important macroeconomic indicators. The social aspects are that employment is a means of livelihood for workers and forms the living standards of the population.

The main characteristics of the employment sector at the regional level are presented in Table 1.

Data from the State Statistics of Ukraine for 2018 showed that only $38.8 \%$ of the current population was employed. The largest percentage of the employed population was observed in Kharkiv region, where it was $47.25 \%$, due to the high 
level of economic development. After all, the Kharkiv region benefits from its territorial and geographical location: due to its proximity to metallurgical and coal districts, metalworking and mechanical engineering have historically developed here; in addition, due to the qualitative characteristics of the land, there is a welldeveloped agriculture. The Kharkiv re- gion's own resources have created favorable conditions for the development of the chemical and fuel industries, the production of building materials and porcelain, etc. The lowest share of the employed population was in Luhansk (13.9\%) and Donetsk regions (17.8\%), which is explained by military actions in eastern Ukraine.

Table 1. Characteristics of the employed population and the average monthly salary in 2018 by the regions of Ukraine

\begin{tabular}{|c|c|c|c|c|}
\hline Regions & \begin{tabular}{|c|} 
Population at \\
January 1,2019 , \\
thousand people
\end{tabular} & $\begin{array}{c}\text { Number, } \\
\text { thousand people }\end{array}$ & $\begin{array}{c}\text { \% of } \\
\text { employed } \\
\text { population }\end{array}$ & \begin{tabular}{|c|} 
The average \\
monthly salary, \\
UAH
\end{tabular} \\
\hline Ukraine & $42,153.2$ & $16,360.9$ & 38.812949 & 8,865 \\
\hline Vinnytsya & $1,560.4$ & 652.7 & 41.8290182 & 7,801 \\
\hline Volyn & $1,035.3$ & 371.1 & 35.8446827 & 7,324 \\
\hline Dnipropetrovsk & $3,206.5$ & $1,402.3$ & 43.73304226 & 8,862 \\
\hline Donetsk & $4,165.9$ & 741.0 & 17.78727286 & 9,686 \\
\hline Zhytomyr & $1,220.2$ & 516.7 & 42.34551713 & 7,372 \\
\hline Zakarpattya & $1,256.8$ & 502.4 & 39.97453851 & 8,070 \\
\hline Zaporizhzhya & $1,705.8$ & 732.2 & 42.92414117 & 8,726 \\
\hline Ivano-Frankivsk & $1,373.3$ & 565.8 & 41.20002913 & 7,551 \\
\hline Kyiv & $1,767.9$ & 755.7 & 42.74563041 & 9,097 \\
\hline Kirovograd & 945.6 & 380.5 & 40.23900169 & 7,191 \\
\hline Luhansk & $2,151.8$ & 298.2 & 13.85816526 & 7,365 \\
\hline Lviv & $2,522.0$ & $1,061.2$ & 42.0777161 & 8,001 \\
\hline Mykolayiv & $1,131.1$ & 496.2 & 43.86880028 & 8,160 \\
\hline Odesa & $2,380.3$ & $1,001.9$ & 42.09133303 & 8,011 \\
\hline Poltava & $1,400.4$ & 580.6 & 41.45958298 & 8,375 \\
\hline Rivne & $1,157.3$ & 473.6 & 40.92283764 & 7,469 \\
\hline Sumy & $1,081.4$ & 485.1 & 44.85851674 & 7,324 \\
\hline Ternopil & $1,045.9$ & 410.8 & 39.27717755 & 6,969 \\
\hline Kharkiv & $2,675.6$ & $1,258.9$ & 47.05112872 & 7,657 \\
\hline Kherson & $1,037.6$ & 448.2 & 43.19583655 & 7,058 \\
\hline Khmelnytskyi & $1,264.7$ & 522.0 & 41.27461058 & 7,346 \\
\hline Cherkasy & $1,206.4$ & 522.6 & 43.31896552 & 7,478 \\
\hline Chernivtsi & 904.4 & 382.9 & 42.3374613 & 6,991 \\
\hline Chernihiv & $1,005.8$ & 429.7 & 42.72221118 & 6,995 \\
\hline The City of Kyiv & $2,950.8$ & $1,368.6$ & 46.38064254 & 13,542 \\
\hline
\end{tabular}

Source: calculated by the author on the basis of the data (State Statistics Service of Ukraine, 2019). 
This problem is due to the relatively high natural population growth, irrational structure of the economy and mainly agricultural specialization of Polissya districts, the lack of jobs. These reasons encourage local people to change their place of residence in order to find work in the southern areas of the region, where industrial enterprises and most of the agricultural land are concentrated. Today it is very difficult to find a job. Employment centers offer vacancies to choose from, but the unemployed are frightened by salaries, which in some cases do not even reach the minimum (Slashchuk and Popiuk, 2013).

Employment depends on the size of salaries, as salary is a motivating factor for employment. The low employment rate in the Volyn region is explained by the low level of average monthly salary in the region (UAH 7,324). However, this is not the lowest salary among the regions of Ukraine. A number of regions are characterized by even lower values of the average monthly salary for 2018 - these are Ternopil, Chernivtsi and Chernihiv regions. But the employment rate for these regions is higher than in Volyn region, which indicates certain regional disparities in the ratio of the employed population and the average salary.

Dnipropetrovsk region is characterized by a fairly high numerical value of the employed population share, which is $43.7 \%$, which exceeds the average value in Ukraine. Dnipropetrovsk region is characterized as a mineral resource, as there are significant reserves of minerals, including reserves of fuel and energy raw materials, due to which there are welldeveloped mining, food industry, metallurgy, energy, crop production. All this forms a powerful industrial complex of Dnipropetrovsk region and provides an opportunity to improve employment. "Dnipropetrovsk region produces $100 \%$ of manganese and almost $80 \%$ of iron ore, $64.1 \%$ of pipes, $27.1 \%$ of rolled metal, $33.3 \%$ of cast iron, $42.6 \%$ of steel, $20.1 \%$ of coke, $17.3 \%$ of cement, $20,0 \%$ of coal, $11.2 \%$ of nitrogen, mineral or chemical fertilizers, $13.7 \%$ of sulfuric acid, $7.3 \%$ of electric motors, $7.5 \%$ of pork, $16.1 \%$ of sausages, $7.6 \%$ of electricity" (Main Department of Statistics in Dnipropetrovsk region, 2019). In 2018, the average salary in the Dnipropetrovsk region was UAH 8,862, which almost coincides with the corresponding indicator for Ukraine.

Analyzing the state and trends of the labor market on the example of Dnipropetrovsk region, we can note trends in the gradual reduction of the number of employed people and increasing unemployment. During the period 2010-2019, the number of employed people in the economy of Dnipropetrovsk region decreased by $8 \%$, which is $5 \%$ lower than the Ukrainian average. The employment rate in 2019 was $59.5 \%$, which is $1.3 \%$ higher than the national average.

According to the diagrams, throughout the study period, there is higher employment rate in Dnipropetrovsk region than in Ukraine, due to the relatively higher level of productive forces development in the region, strong production potential and developed infrastructure. The previous research has shown that the region is at the forefront of economic and social development.

There is also a positive trend in the growth of the average level of salaries in the region, which is higher than the average in Ukraine.

Statistics show that the average monthly salary in the region during the study period is higher than in Ukraine by 
$2-3 \%$.

Despite some improvements in some sectors and a nominal increase in the average salary, there are some threatening trends in the labor market of Ukraine in terms of rising unemployment, the development of "hidden employment" and the emigration of much of the labor potential abroad. All this leads to significant distortions of the labor market, reduction of contributions to the pension fund and deterioration of living standards. In this context, we agree with the opinion of L. Strembitska that “in today's conditions, the labor market is formed under the influence of negative factors of economic dynamics, deterioration of foreign economic conditions, rising cost of credit resources, extremely low effective demand. In addition, in recent years, military action in the east of our country has been added to the established list of negative factors that created an imbalance in the labor market of Ukraine. The spread of crises in the economy typically causes a sharp imbalance between labor supply and demand. This leads to the impossibility of full and high-quality labor reproduction, increased competition, which in such conditions is not able to perform the function of an effective element of the market mechanism, but acquires qualities that lead to extreme tensions in the labor market and cause imbalance of all its components, increasing socio-economic threats and contradictions in society" (Strembitska, 2017).

Recent trends in both the national and global economies under the influence of adverse economic situations in world markets, reduced business activity in the manufacturing sectors through quarantine measures and the rapid development of digital technologies require a review and optimization of existing regional policies to find reserves in order to provide a sufficient employment rate in the strategic perspective.

The employment rate is determined by various factors, among which scientists highlight the level of economic development and the effectiveness of public policy in the field of employment, the state of the business environment, competitiveness and effective structure of economic sectors in the region.

One of the factors that create demand, supply, working quality requirements and its prices in the labor market is the sectoral structure of the economy. According to L. Fedunchyk "the sectoral structure of the labor market characterizes the aggregate demand of society for labor of the economy sectors, which is confirmed by real jobs. $n$ the national economy, the distribution of workers by industries and spheres of production may indicate the direction and progress of the country's economic development. With an unsatisfactory distribution of the employed population, this may indicate the likelihood of contradictions and losses between production, industries and sectors of the economy" (Fedunchyk, 2017).

In the context of decentralization, an important factor in the development of a region or territorial community is to provide the competitiveness of the regional economy and the search for the most optimal structure that will provide sustainable growth of the economic system and appropriate living standards.

According to T. Trubnik "identifying the structural effect allows us to assess the positive or negative impact on changes in the overall effectiveness of structural changes in the redistribution of the components. The result of structural changes is a natural redistribution of productive re- 
sources in favor of those sectors, elements of a market economy that are better adapted to survive in new conditions and have the appropriate potential to achieve maximum effect from activities" (Trubnik, 2012).

Different methodological approaches are used to assess the effectiveness of the structural transformation of the region's economy in the conditions of external changes. In particular, correlationregression analysis, index analysis, clusters analysis, etc. Shift-share analysis is one of the methodological approaches widely used to determine the competitiveness of regional industries, assess and predict the relative growth of the region's economy, the optimality of structural changes and other areas of economic research in the US and Western Europe. The main idea of the approach is that the rate of regional growth depends on three factors: the sectoral structure of the economy, the productivity of industries and the dynamics of demand and consumer preferences.

The method is used by Ukrainian and foreign scientists to study the effectiveness of regional development under the influence of national, industrial and regional effects. In particular, T. Trubnik used a methodology to determine the competitiveness of the economy of the Ukrainian regions using the value added index produced by various types of economic activity. According to the author "The research methodology is as follows: the general change in the quantitative indicator is divided into three components - national, sectoral and regional. The first one takes into account the growth of the studied indicator in the national economy (National Share - NS); the second one takes into account shifts provided by the com- position effect (proportion effect - industry mix or MIX effect), which is influenced by the sectoral structure and is provided by the difference between the sectoral and national rate of change; the third component takes into account shifts due to the effect of competition (differentiated shift - DIF effect), which is based on the assumption that each industry of the sector (region) is better or worse developed compared to its development on a national scale" (Trubnik, 2012).

According to T. Trubnik and O. Mazurenko "The sectoral structure reflects the relationships and interrelationships between the aggregates of economic units (sectoral economies) and is determined by the internal structure of the economy, the balance or imbalance of supply and demand. The sectoral effect is assessed, first of all, from the standpoint of progressiveness, innovation of economic activities and their efficiency. The sectoral structure is relatively stable, and it takes a certain period of time to transform it in the direction set by market needs. Most often, such progressive changes are associated with modern technologies that provide the development of innovationoriented industries with a high level of competitiveness" (Trubnik and Mazurenko, 2019).

We agree with the opinion of scientists U. Sadova and T. Stepura that The formation of an effective employment policy in the region should be based on "a balanced approach to solving economic and social problems - formation of an effective structure of employment, growth of labor productivity, providing a socially acceptable level of employment, increase in incomes, which together aims at the development of human potential" (Sadova and Stepura, 2018). 
An objective monitoring system, as opposed to that practiced now, should exclude the inflation component, and the main macroeconomic indicators should be determined per capita people. This will allow for more objective conclusions and predictions on the level of economic development and compare relevant indicators as in dynamics and at different levels of aggregation (country, region, territorial community). In addition, the basis for monitoring should not be only the development of indicators in the dynamics, and effective management economic processes, which is reflected in certain regulations (target) indicators defined in the relevant planning documents.

The team of authors believes that "No less important factor in economic growth and long-term economic balance in the economy is a quality investment structure. As the experience of economically developed countries, the priority areas of investment potential that create the basic foundations of a competitive economy Unfortunately, in Ukraine in recent decades, these areas have not been a priority of public investment policy, which has led to a significant technological backlog of most domestic industries in the world market, significant loss of human capital and the adoption of a model of commodity-oriented economy" (Irtyshcheva and Kramarenko, 2014).

The important criteria for the effectiveness of regional employment policy are not only the increase in employment and reduction of unemployment, but also the efficiency of jobs in terms of providing workers with a sufficient level of salaries, occupational safety and conditions for the labor potential development. In addition, jobs must be official, which will allow the state and regional authorities to form a budget, provide social spending and finance the development of social infrastructure (Kramarenko, Voit and Kravets, 2019).

\section{Conclusions.}

It is noted that providing a sufficient employment rate and decent working conditions is one of the important indicators and, at the same time, factors of socioeconomic development of the region. In order to determine the dependence of employment in Dnipropetrovsk region on the influence of the structural, regional and national factors, a shift-share analysis was conducted. The results of the analysis showed that the greatest influence on providing the employment rate in the Dnipropetrovsk region is exerted by the factors of the regional economy, namely the competitiveness of the sectors, including primarily industry, wholesale and retail trade, transport. Almost all types of economic activity are internally competitive, which in 2018 provided the current employment rate by $89 \%$, i. e. $1,245.4$ thousand employees. Given the preservation of national dynamics in the region, the number of employees in the region as a whole would be lower by $9 \%$ or 133 thousand people. The largest reductions would be in industry, trade and education.

The graphic analysis of employment in terms of economic activities in Dnipropetrovsk region revealed the most promising economy sectors in the region in terms of job creation and providing a sufficient employment rate. Each type of economic activity is represented by a point with corresponding coordinates, which shows the growth of employment in the sector at the national $(X)$ and regional level $(Y)$ and the share of economic activity in the region's economy. The graphic analysis shows that the most productive 
sectors of the region's economy in terms of job growth are wholesale and retail trade, agriculture and forestry.

The research shows that the main problem of managing the region's strategic development at the current stage is primarily the lack of a comprehensive conceptual strategic vision of the region's model, which will provide a balance of interests between government, business, the public, unite the efforts of all actors in the regional system to achieve common and mutually beneficial goals aimed at sustainable economic growth, providing the welfare of citizens and the most optimal use of resources. Such goals, in our opinion, should be the imperatives of strategic development of the region, which will act as a cross-cutting regulator of socio-economic processes and decisionmaking at all levels.

\section{References}

Cabinet Ministers of Ukraine (2016), Resolution of the Cabinet Ministers of Ukraine "State target social program "Youth of Ukraine" for 2016-2020", available at: https://zakon.rada.gov.ua/laws/show/148-2016-\%D0\%BF\#Text (Accessed 20 October 2019)

Fedunchyk, L. G. (2017), "The existence of a structural imbalance in demand and supply of the Ukrainian labor market”, Efektyvna ekonomika, [Online], no. 12, available at: http://www.economy.nayka.com.ua/?op=1\&z=5982 (Accessed 20 October 2019)

Grineva, N. A. (2010), "Estimation procedure of regional competitiveness", Scientific sheets of Belgorod State University. Series: History. Political science. Economics. Informatics, no. 13(84), issue 15/1, pp. 15-22.

Irtyshcheva, I. O. and Kramarenko, I. S. (2014), "Investment attractiveness of the economy: interregional asymmetries”, Regional Economy, no. 2(72), pp. 84-95.

Irtyshcheva, I., Voit, D., Pavlenko, H. and Arhangelska, A. (2019), "Monitoring of socio-economic development of Ukraine end region", The Bulletin of the Kharkiv National Agricultural University named after V. V. Dokuchaev. Series "Economic Sciences", no. 2, pp.403-413. doi: http://dx.doi.org/10.31359/2312-3427-2019-2-406

Kramarenko, I. S., Voit, D. S. and Kravets, L. O. (2019), “Efficiency of using the investment potential of the national economy in the context of the impact on economic growth", The Bulletin of the Kharkiv National Agricultural University named after V. V. Dokuchaev. Series "Economic Sciences", no. 1, pp. 403-413. doi: http://dx.doi.org/10.31359/2312-3427-2019-1-403

L'uboš, E., Lesáková, L'., Klementová, V. and Klement, L. (2019), "Identification of prospective industrial clusters in Slovakia”, Engineering Management in Production and Services, vol. 11, no. 2, pp. 31-42. https://doi.org/10.2478/emj-2019-0009

Main Department of Statistics in Dnipropetrovsk region (2019), “Statistical information", available at: http://www.dneprstat.gov.ua/statinfo/ (Accessed 20 October 2019).

Sadova, U. and Stepura, T. (2018), "Job opportunities as the basis of the new employment policy and recreation of the quality of human potential in Ukraine”, Labor market and employment, no. 2, pp. 15-22.

Slashchuk, A. and Popyuk, Z. (2013), "Labor market and the problem of unemployment in the Volyn region", Scientific Bulletin of the Lesia Ukrainka East European National University. Series: Geographical Sciences. no.6. pp. 112-117, available at: http://nbuv.gov.ua/UJRN/Nvvnug 2013621 (Accessed 20 October 2019)

State Statistics Service of Ukraine (2019), "Statistical collection "Regions of Ukraine 2019”, available at: http://www.ukrstat.gov.ua/druk/publicat/kat u/2019/zb/12/zb ru1ch2019.pdf (Accessed 20 October 2019) 
Strembitska, L. L. (2017), "Modern trends in the labor market in terms of threats to Ukraine's economic security”, Economies' Horizons, no. 1(2), pp. 88-95. doi: https://doi.org/10.31499/2616$\underline{5236.1(2) .2017 .113316}$

Trubnik, T. E. (2012), "Using the method "shift - share" analysis for evaluation the quality of sectoral change", Efektyvna ekonomika, [Online], no. 7, available at: http://www.economy.nayka.com.ua/?op=1\&z=1281 (Accessed 20 October 2019)

Trubnik, T. Ye. and Mazurenko, O. K. (2019), “The shift-share method: an instrument for analyzing the dynamics of industry structure of the economy", Statistics of Ukraine, no. 4, pp. 36-47. doi: https://doi.org/10.31767/su.4(87)2019.04.05

Zsarnoczky, M. (2018), "Shift-share analysis of the impact of tourism on local incomes in Hungary" Geografijos metraštis, vol. 51, pp. 47-60.

Цей твір ліцензовано на умовах Ліцензії Creative Commons «/з Зазначенням Авторства - Некомерційна 4.0 Міжнародна» (CC BY-NC 4.0). This is an open access journal and all published articles are licensed under a Creative Commons "Attribution-NonCommercial 4.0 International" (CC BY-NC 4.0). 